$14^{\text {th }}$ Conf. Agric. Develop. Res., Fac. of Agric., Ain Shams Univ.,

March, 2019, Cairo, Egypt

Special Issue, 27(1), 717 - 726, 2019

Website: http://strategy-plan.asu.edu.eg/AUJASCl/

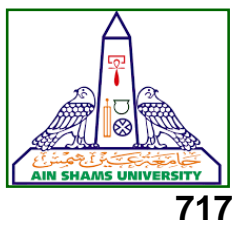

\title{
INFLUENCE OF SPROUTING USING BIOTIC AND ABIOTIC ELICITORS ON CHEMICAL COMPOSITION OF RADISH SEEDS (RAPHANUS SATIVUS)
}

\author{
Islam M. Tork ${ }^{1 *}$, Abdelhafez ${ }^{2}$ A.A.M., Fatma A.A. Mostafa ${ }^{1}$ \\ and Abdallah ${ }^{3}$ M.M.F.
}

1. Regional Center for Food and Feed, Agricultural Research Center (ARC), Giza, Egypt

2. Agric. Microbiology Dept., Fac. of Agric., Ain Shams Univ., P.O. Box 68, Hadyek Shoubra11241, Cairo, Egypt

3. Hortic. Dept., Fac. of Agric, Ain Shams Univ., P.O. Box 68, Hadyek Shoubra11241, Cairo, Egypt

*Corresponding author: islamtork2008@gmail.com

Received 13 October, 2018, $\quad$ Accepted 31 October, 2018

\section{ABSTRACT}

Germination is a way to improve agricultural productivity and easily to use by low income families, in particular with using some elicitors in germination for enhancing the nutrition value of the seeds by sprouting. For their highly metabolic activities after harvesting, radish seeds were selected for performance of this study. The effect of using abiotic elicitor (saline water, by $\mathrm{NaCl}$ at different concentrations) and biotic elicitor (Saccharomyces cerevisiae) on sprouting of radish seed has been investigated. After germinating radish seeds for six days using elicitors, chemical analysis and determination for phytochemicals contents have been carried out. Results showed a promising efficiency by sprouting, where an appreciable increasing in some analysis as protein, carbohydrates, some minerals and amino acids comparing to seed. Besides, germination had a positive effect to present some phyto-compounds as some flavonoids, terpenoids and phenolic compounds. Then, this study and similar ones are an important step towards the future development of value-added foods with elicited phytochemicals and can be used in the development of innovative food products with beneficial effects on human's health.

Key words: Radish seed, Elicitors, Biotic, Abiotic

\section{INTRODUCTION}

Demanding for food will continue to increase towards 2050, as a result of population growth. Increases in food production per hectare of land have not kept pace with increasing in population which leads to the global food crisis. The world food crisis is the result of the effects of competition for cropland from the growth in biofuels, low cereal stocks, high oil prices, speculation in food markets and weather events. One possible solution to the global food crisis is to improve agricultural productivity by some means (Sarinont et al 2014).

It is worth to mention that many children, under five years, suffer from protein energy malnutrition during the introduction of complementary foods. In matter of fact, infants at this stage of rapid development have high requirements of energy and nutrients per unit body weight. There is need therefore to develop appropriate nutrient-dense complementary foods that could be used by low income families.

Germination brought about significant increases in the micronutrient, phytonutrient content of all selected seeds, thus proving that there is marked increase in the nutritive value of the seeds on sprouting. This ultimately signifies that sprouts should be considered a vital component of the diet and can be incorporated to improve agricultural productivity and easily to use by low income families (Wagner et al 2013). 
Cruciferous sprouts are distinctive plant foods because of their rich composition in bioactive compounds compared to other plants. Germinating seeds may contain more than doubles of phytochemicals depending the species, cultivar, and environmental conditions. Seven or eight days old sprouts are of appropriate age for harvest allowing post-harvest handling and marketing of this material, maintaining contents of phytochemicals higher than other vegetables. Radish sprouts are very young plants that continue their highly metabolic activities after harvesting (Baenasa et al 2017).

Radish belongs to Cruciferous family. Radishes have been cultivated for thousands of years in both China and the Mediterranean area. In general, radish contains carbohydrates, sugars, dietary fibers, protein and fat. Radish was found to have unique bioactive compounds that have been recognized to have potential health benefits to humans (Aly, Tahany 2015).

Many researches have been focused on developing efficient strategy for enhancing production of useful metabolites in food plants without gene modification or breeding Paskin et al (2002). As the biosynthesis of several secondary metabolites in plants is usually a defense response of plants to biotic and abiotic stresses, their performance can be effectively stimulated by biotic and abiotic elicitors, making elicitation is one of the most effective strategies for improving bioactive secondary metabolite production in plant tissue Mulabagal and Tasy (2004). Yeast polysaccharide (YPS) is an efficient biotic elicitor for stimulating secondary metabolite production in plant cell Zhao et al (2010). Production of many valuable bioactive compounds has been successfully stimulated by YPS elicitors (Zhao et al 2012).

Since the scientific information regarding the effect of biotic and abiotic elicitors on bioactive chemical compounds remains limited, this paper aims to fill this knowledge gap. Radish seed was selected for performance of this study. Then a comparing study between the chemical analysis and phytochemical contents of the selected dry seed and their germinated samples and that including using abiotic elicitor (saline water by $\mathrm{NaCl}$ salt) and biotic elicitor (Saccharomyces cerevisiae yeast)

\section{MATERIALS AND METHODS}

This study was carried out in Horticulture Department, Faculty of Agriculture, Ain Shams University, Cairo and the Regional center for Food and Feed (RCFF), Agricultural Research center (ARC), Giza, Egypt.

\section{Radish seeds}

Seeds of Egyptian radish (Raphus sativus), Balady cultivar, were obtained from privet farm in Kalubia government.

\section{Effect of $\mathrm{NaCl}$ concentration on radish sprout- ing}

Washing seeds to be sure that it is cleaned and not good seed has been excluded. Sprouting of seeds was done by using tap water (as control) and consequent concentration of $\mathrm{NaCl}$ (1000 ppm, 2000 ppm, 3000 ppm and 4000 ppm). Twenty grams of radish seeds were placed in glass jar, containing $200 \mathrm{ml}$ of either tap water or saline water and soaked for 12 hours at room temperature After that, soaking water was removed then seeds were washed every 8 hours using the same soaking solution, for 3 days. At the end of sprouting period, samples of radish sprouts were collected for measuring sprout characters Eman Tork (2017).

According to the best results for sprout hypocotyl length and whole sprout length, the appropriate concentration for $\mathrm{NaCl}$ was selected for performance the sprouting of radish seed and making the chemical analysis, phytochemical contents of the selected dry seeds and their germinated samples. Samples of harvested germinated and seeds were collected after six days dried in oven at $60^{\circ} \mathrm{C}$ for $48 \mathrm{~h}$ then ground in laboratory Wiley mill to pass through a 40-mesh sieve. The ground sample was stored at $5^{\circ} \mathrm{C}$ until analysis Eman Tork (2017).

\section{Chemical analysis \\ Proximate analysis}

Total protein, fats, fiber and ash were analyzed according to AOAC (2012), Total carbohydrates were determine by difference.

\section{Determination of minerals concentration:}

Calcium (Ca), magnesium $(\mathrm{Mg})$, Iron $(\mathrm{Fe})$, Copper ( $\mathrm{Cu})$, Zinc $(\mathrm{Zn})$, sodium ( $\mathrm{Na}$ ) and potassium $(\mathrm{K})$ were analyzed by ICP/MS/MS Agilent 8800 according to the method described in the AOAC (2012). 
Influence of sprouting using biotic and abiotic elicitors on chemical composition of 719 radish seeds (Raphanus sativus)

\section{Amino acids analysis}

Amino acids determination was performed according to AOAC (2012), using Eppendorf LC 3000 EZ chrom.

\section{Fatty acids analysis}

Saturated and unsaturated fatty acids were determined using methyl esters boron trifluoride method according to AOAC (2012), using GC instrument (chemazo).

\section{Screening of phytochemical compounds:}

Determination of phytochemicals compounds were performed according to the method described by Santana et al (2013) using GC/MS/MS technique.

The analysis was carried out using a GC (Agilent Technology 7890A) coupled with a massselective detector (MSD, Agilent 7000 Triple Quad) equipped with Agilent HP-5ms capillary column.

The identification of components was based on a comparison of their mass spectra with the authentic compounds and by computer matching with NIST library as well as by comparison of the fragmentation pattern of the mass spectral data with those registered in the literature.

\section{RESULTS AND DISCUSSION}

\section{Effect of $\mathrm{NaCl}$ concentrations on sprouting of radish seed:}

Table (1) showed radish sprout (6 days old) length, fresh and dry weight and its radical and hypocotyl length. Mean of sprout radical length varied between 3.5 and $4.8 \mathrm{~cm}$ at various $\mathrm{NaCl}$ concentrations. The longest radical length was observed in the control and in $2000 \mathrm{ppm} \mathrm{NaCl}$. Similar results were show in sprout hypocotyl length and whole sprout length, with significant decrement at 3000 and 4000 ppm NaCl compared with control. On the other hand the results showed that the $2000 \mathrm{ppm} \mathrm{NaCl}$ sprout has the heights values for the sprout length, sprout fresh weight and sprout dry weight. Then, 2000 ppm NaCl concentration is the appropriate concentration for performance the sprouting of radish seed for making the chemical analysis and phytochemical contents.
Table 1. Effect of $\mathrm{NaCl}$ concentration on Egyptian radish sprouts characteristics

\begin{tabular}{|c|c|c|c|c|c|}
\hline $\begin{array}{c}\mathrm{NaCl} \text { Concen- } \\
\text { tration }\end{array}$ & $\begin{array}{c}\text { Sprout } \\
\text { radical } \\
\text { length } \\
(\mathrm{cm})\end{array}$ & $\begin{array}{c}\text { Sprout } \\
\text { hypocotyl } \\
\text { length } \\
\text { (cm) }\end{array}$ & $\begin{array}{c}\text { Sprout } \\
\text { length } \\
(\mathrm{cm})\end{array}$ & $\begin{array}{c}10 \\
\text { sprouts } \\
\text { fresh } \\
\text { weight } \\
\text { (mg) }\end{array}$ & $\begin{array}{c}10 \\
\text { sprouts } \\
\text { dry } \\
\text { weight } \\
\text { (mg) }\end{array}$ \\
\hline $\begin{array}{c}\text { Control(Tap } \\
\text { water) }\end{array}$ & $4.7^{\mathrm{a}}$ & $4.5^{\mathrm{ab}}$ & $9.2^{a}$ & $1110^{a}$ & $93^{a}$ \\
\hline $1000 \mathrm{ppm}$ & $4.5^{\mathrm{a}}$ & $4.5^{\mathrm{ab}}$ & $9.0^{\mathrm{a}}$ & $1070^{a}$ & $83^{a}$ \\
\hline 2000 ppm & $4.8^{a}$ & $4.9^{\mathrm{a}}$ & $9.7^{\mathrm{a}}$ & $1253^{a}$ & $93^{a}$ \\
\hline 3000 ppm & $3.6^{b}$ & $3.9^{b c}$ & $7.5^{b}$ & $460^{b}$ & $83^{a}$ \\
\hline 4000 ppm & $3.5^{b}$ & $3.6^{c}$ & $7.1^{b}$ & $300^{b}$ & $80^{a}$ \\
\hline LSD at $0.5 \%$ & 0.7 & 0.7 & 1.2 & 0.3 & NS \\
\hline
\end{tabular}

Means in each column followed by the same letter are not significantly different at the $5 \%$ level

\section{Proximate analysis of radish seed sprouts:}

Results of proximate analysis of radish seeds and its sprouts using irrigated tap water, saline water $(2000 \mathrm{ppm} \mathrm{NaCl})$, tap water with yeast $(1 \%)$ and saline water with yeast (1\%) are shown in Table (2). Data in Table (2) display that protein, moisture, ash, fiber and carbohydrates noticeable increased in all treatments, while lipid decreased in all treatments. That was comporting with Fouad \& Rehab (2015) who studied effect of germination for 6 days on proximate analysis of lentil. These results were agreed with Aly, Tahany et al., (2018) who studied green radish sprouts (8 days old).

Data also showed that yeast had a positive effect on protein, where sprouting with yeast caused an increase in protein content comparing with sprouting with tap or saline water only. The increase in sprout protein content may be due to reduction of seed nitrates into plant protein (metabolic enzymes) or nitrogen fixation during germination.

Table 2. Proximate analysis of radish etiolated sprouts using different irrigation treatments

\begin{tabular}{|c|c|c|c|c|c|c|}
\hline Treatments & $\begin{array}{c}\text { Pro- } \\
\text { tein }\end{array}$ & $\begin{array}{c}\text { Mois- } \\
\text { ture }\end{array}$ & ASH & $\begin{array}{c}\text { Total } \\
\text { lipid }\end{array}$ & Fiber & $\begin{array}{c}\text { Carbohy- } \\
\text { drates }\end{array}$ \\
\hline Seed & 22.5 & 4.5 & 4.11 & 32.27 & 13.63 & 22.99 \\
Tap water & 24.3 & 5.53 & 10.11 & 8.96 & 17.64 & 33.46 \\
$\begin{array}{c}\text { Tap water + } \\
\text { Yeast }\end{array}$ & 25.9 & 5.91 & 9.05 & 10.11 & 15.47 & 33.56 \\
$\begin{array}{c}\text { Saline water } \\
\text { Saline water } \\
+ \text { Yeast }\end{array}$ & 26.2 & 5.8 & 10.08 & 8.84 & 17.21 & 31.87 \\
\hline
\end{tabular}




\author{
Minerals content of Egyptian radish seed \\ sprouts
}

Minerals contents of sprouts are shown in Table (3). There was an increase in $\mathrm{Fe}, \mathrm{Mg}, \mathrm{K}$ and $\mathrm{Zn}$ contents in sprouts treated with tap or saline water. $\mathrm{Na}$ content was increased in the sprouts treated with saline water and saline water + yeast treatments, which is attributed to the $\mathrm{NaCl}$ in the saline solution used for rinsing seeds during germination. The highest increases in $\mathrm{Cu}$ and $\mathrm{Zn}$ were observed in "Tap water + yeast" treatment. This increasing in these elements was observed too in the study Aly, Tahany et al (2018) on green radish sprouts.

Table 3. Mineral content of radish sprouts vs dry seed

\begin{tabular}{|cccccccc|}
\hline $\begin{array}{c}\text { Irrigation } \\
\text { Treatments }\end{array}$ & $\begin{array}{c}\mathrm{Ca} \\
\%\end{array}$ & $\begin{array}{c}\mathrm{Fe} \\
\%\end{array}$ & $\begin{array}{c}\mathrm{Mg} \\
\%\end{array}$ & $\begin{array}{c}\mathrm{K} \\
\%\end{array}$ & $\begin{array}{c}\mathrm{Na} \\
\%\end{array}$ & $\begin{array}{c}\mathrm{Cu} \\
\mathrm{ppm}\end{array}$ & $\begin{array}{c}\mathrm{Zn} \\
\mathrm{ppm}\end{array}$ \\
\hline Dry seeds & 0.24 & 0.05 & 0.24 & 0.75 & 0.01 & 5.42 & 41.8 \\
$\begin{array}{c}\text { Tap water } \\
\text { Tap water } \\
\text { +yeast }\end{array}$ & 0.22 & 0.41 & 0.41 & 3.00 & 0.33 & 6.92 & 47.7 \\
$\begin{array}{c}\text { Saline water } \\
\text { Saline water }\end{array}$ & 0.26 & 0.48 & 0.42 & 3.34 & 1.85 & 6.37 & 50.0 \\
+yeast & 0.25 & 0.47 & 0.42 & 2.69 & 2.37 & 6.48 & 49.3 \\
\hline
\end{tabular}

\section{Fatty acids analysis:}

Results of fatty acids in radish seeds and their sprouts are shown in Table (4). Some of fatty acids such as linoleic acid, linolenic acid showed an increasing in sprout samples as compared with seeds. Other fatty acids were less than $0.1 \%$ in seed, sprouts with tap and saline water but show markable high concentration in sprouts treated with Saccharomyces cerevisiae yeast these fatty acids included Plamitioleic acid (C16:1w9), Lignoceric acid and Nervonic acid. Others Eicosaenoic acid and 11 -Eicosaenoic acid were less than $0.1 \%$ in seeds but they were higher in sprouts in all treatment. And other fatty acids have shown decreasing concentration in sprouts samples less than radish seed as: lauric acid, myristic acid and plamitic acid. Similar results for the increasing and decreasing fatty acids content were obtained by Marton et al $\mathbf{2 0 1 0}$ during their research on fatty acid content of sprouts of radish seed after 6 days of germination.
Table 4. Fatty acids content of Egyptian radish sprouts vs. dry seeds (mg/100mg D.W.)

\begin{tabular}{|c|c|c|c|c|c|}
\hline Fatty acid & $\begin{array}{l}\text { Dry } \\
\text { Seeds }\end{array}$ & $\begin{array}{l}\text { Tap } \\
\text { water }\end{array}$ & $\begin{array}{c}\text { Tap } \\
\text { water }+ \\
\text { yeast }\end{array}$ & $\begin{array}{l}\text { Slain } \\
\text { water }\end{array}$ & $\begin{array}{c}\text { Slain } \\
\text { water } \\
\text { +yeast }\end{array}$ \\
\hline \begin{tabular}{|l|} 
Lauric acid (C12:0) \\
\end{tabular} & 0.72 & 0.49 & 0.58 & 0.61 & 0.42 \\
\hline $\begin{array}{c}\text { Myristic acid } \\
\text { (C14:0) }\end{array}$ & 1.85 & 0.74 & 0.72 & 1.05 & 0.53 \\
\hline $\begin{array}{c}\text { Plamitic acid } \\
\text { (C16:0) }\end{array}$ & 9.94 & 7.06 & 6.43 & 7.9 & 6.68 \\
\hline $\begin{array}{c}\text { Plamitioleic acid } \\
\quad(\mathrm{C} 16: 1 \mathrm{w} 9)\end{array}$ & $<0.1$ & $<0.1$ & 0.43 & $<0.1$ & 0.49 \\
\hline $\begin{array}{l}\text { Plamitioleic ac- } \\
\text { id(C16:1wh7) }\end{array}$ & 0.62 & 0.68 & 0.96 & 0.56 & 1.04 \\
\hline Stearic acid (C18:0) & 3.69 & 2.24 & 2.38 & 2.66 & 2.15 \\
\hline $\begin{array}{l}\text { Oleic acid } \\
(\mathrm{C} 18: 1 \omega 9)\end{array}$ & 17.39 & 16.28 & 16.23 & 15.71 & 16.11 \\
\hline $\begin{array}{l}\text { Linoleic acid } \\
(C 18: 2 \omega 6)\end{array}$ & 12.46 & 12.25 & 13.75 & 14.11 & 13.81 \\
\hline $\begin{array}{l}\text { Linolenic acid } \\
\quad(C 18: 3 \omega 3)\end{array}$ & 9.98 & 12.24 & 13.89 & 11.06 & 14.15 \\
\hline $\begin{array}{c}\text { Stearidonic acid } \\
(C 18: 4 \omega 3)\end{array}$ & $<0.1$ & $<0.1$ & $<0.1$ & 0.42 & 0.38 \\
\hline $\begin{array}{l}\text { Arachidic acid } \\
\text { (C20:0) }\end{array}$ & 1.04 & 1.07 & 1.03 & 1.02 & 0.98 \\
\hline 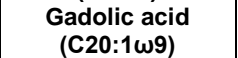 & 6.45 & 3.64 & 5.2 & 3.36 & 5.12 \\
\hline $\begin{array}{c}\text { Eicosaenoic acid } \\
\text { (C20:1w11) }\end{array}$ & $<0.1$ & 5.3 & 2.09 & 5.19 & 2.11 \\
\hline 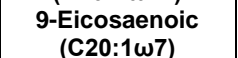 & 0.52 & $<0.1$ & 0.31 & $<0.1$ & 0.32 \\
\hline $\begin{array}{l}\text { 11-Eicosaenoic } \\
\text { (C20:1 } 25)\end{array}$ & $<0.1$ & 0.48 & 0.52 & 0.5 & 0.5 \\
\hline $\begin{array}{c}\text { Eicosadienoic acid } \\
\text { (C20:2w6) }\end{array}$ & 0.62 & 0.55 & 0.44 & 0.53 & 0.45 \\
\hline $\begin{array}{l}\text { Behenic acid } \\
(\mathrm{C} 22: 0)\end{array}$ & 1.13 & 1.21 & 1.23 & 1.21 & 1.14 \\
\hline $\begin{array}{l}\text { Erucic acid } \\
(\mathrm{C} 22: 1 \omega 9)\end{array}$ & 32.96 & 35.32 & 30.43 & 34.06 & 30.17 \\
\hline $\begin{array}{l}\text { Lignoceric acid } \\
(C 24: 0)\end{array}$ & $<0.1$ & $<0.1$ & 1.58 & $<0.1$ & 1.77 \\
\hline 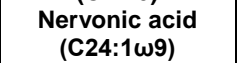 & $<0.1$ & $<0.1$ & 1.6 & $<0.1$ & 1.65 \\
\hline $\begin{array}{c}\text { Non identified fatty } \\
\text { acid }\end{array}$ & 0.63 & 0.45 & 0.2 & 0.05 & 0.03 \\
\hline
\end{tabular}

\section{Amino acids Results}

Table (5) screens the amino acids results for radish seed and its sprouts. In radish sprouts, most of amino acids percentage were noticeably increased for all treatments. This increasing compared to radish seed could be attributed to the increasing in protein contents in all sprout treatments, especially with using saline water with yeast, which showed the highest protein percentage. As long as there was a shift from storage protein to functional protein during sprouting there was an increasing in free amino acids and their availability in sprouts. Besides, the increase in free amino acid percentage depends not only on its amino acid composition but also on the availability of these amino acids as statement by Aly, Tahany et al (2018). 
Table 5. Amino acids percentage of radish sprouts vs. dry seeds $(\mathrm{g} / 100 \mathrm{~g})$

\begin{tabular}{|c|c|c|c|c|c|}
\hline T.A.A \% & $\begin{array}{c}\text { Dry } \\
\text { Seeds }\end{array}$ & $\begin{array}{c}\text { Tap } \\
\text { water }\end{array}$ & $\begin{array}{c}\text { Tap } \\
\text { water } \\
\text { +yeast }\end{array}$ & $\begin{array}{c}\text { Slain } \\
\text { water }\end{array}$ & $\begin{array}{c}\text { Slain } \\
\text { water } \\
\text { +yeast }\end{array}$ \\
\hline Aspartic acid(ASP) & 1.88 & 1.92 & 1.96 & 1.91 & 1.99 \\
Therionine (Thr) & 0.89 & 0.9 & 0.93 & 0.91 & 0.95 \\
Serine (Ser) & 0.88 & 0.91 & 0.94 & 0.91 & 0.95 \\
Glutamic (Glu) & 2.0 & 2.07 & 2.78 & 2.03 & 2.95 \\
Proline (Pro) & 0.99 & 0.98 & 1.11 & 1.09 & 1.13 \\
Glycine (Gly) & 0.97 & 0.95 & 1.0 & 0.96 & 0.99 \\
Alanine (Ala) & 1.18 & 1.22 & 1.38 & 1.29 & 1.48 \\
Valine (Val) & 0.94 & 0.99 & 1.1 & 1.01 & 1.12 \\
Isoleucine (Iso) & 0.63 & 0.7 & 0.81 & 0.72 & 0.81 \\
Leucine (leu) & 0.95 & 1.07 & 1.29 & 1.12 & 1.4 \\
Tyrosin (Tyr) & 0.61 & 0.7 & 0.73 & 0.68 & 0.75 \\
Phenylalanine (Phe) & 0.7 & 0.84 & 0.91 & 0.88 & 0.98 \\
Histidine (His) & 0.65 & 0.66 & 0.7 & 0.67 & 0.7 \\
Lysine (Lys) & 0.89 & 1.04 & 1.2 & 1.09 & 1.26 \\
Arginine (Arg) & 0.9 & 1.1 & 1.2 & 1.09 & 1.22 \\
Cyaseine (Cys) & 0.32 & 0.34 & 0.4 & 0.34 & 0.45 \\
Methonine (Meth) & 0.19 & 0.24 & 0.3 & 0.26 & 0.32 \\
\hline
\end{tabular}

\section{Phytochemical screening of seed and sprouts}

The obtained chromatogram for phytochemical screening compounds of radish seed are shown in Fig. (1) and the chromatogram for phytochemical compounds of radish sprouts using tap water, tap water with Saccharomyces cerevisiae, saline water and saline water with Saccharomyces cerevisiae are shown in Figs. 2, 3, 4 \& 5, respectively. The whole recognized compounds are tabled in Table (7). It seems from the results in Table (7) that germination had a positive effect to present some phyto-compounds which weren't exist in the seed. Some of these compounds are flavenoids like as: Pentahydroxyflavone, 4-Methylthio-3-butenyl isothiocyanate, 3'-Hydroxy-5, 6, 7, 4'-tetramethoxy flavone and Isovitexin. Other compounds are phenolic compounds as Phloroglucinol or terpenoids as $\beta$-Terpinyl acetate and phytol. Also the compounds which appear only in sprouts are sulfur compounds such as Thiophene, 2- butyltetrahydro and diNonyl sulfide. It can be said that sprouting radish seed could produce various phytochemicals that improve health.

There were several compounds, that had different activity with saline water and Saccharomyces cerevisiae treatment. For example, Pentahydroxyflavone (flavonoid) was noticed to increase in Saccharomyces cerevisiae treatment with both tap and saline water. Some other compounds have obviously increased in saline water, with and without Saccharomyces cerevisiae, like: $\beta$-Curcumene (phenol), Glucofuranosylbenzenesulfonate (sulfur compound), Hydroxy-5,6,7,4'-tetramethoxyflavone (flavonoid) and Isovitexin (flavonoid). That beside to phytol (terpenoid), which wasn't present in seed, but it was existed in all sprouts and greatly increased in sprout treatment with saline water and Saccharomyces cerevisiae.

From above, flavonoids, a class of secondary plant metabolites with significant antioxidant and chelating properties were found to increase in sprouting especially with using Saccharomyces cerevisiae elicitor. All this reflects the possibility of sprouting on development of new phytochemicals compounds which has been shown by Dongyan et al (2014) in their study in mung bean sprouts. They cleared that under biotic and abiotic stress, plant physiology dramatically changes. Moreover, there were dynamic changes in metabolites during sprouting process including flavonoids, phenolic compounds, organic acids and amino acids. As a result, accumulation of secondary metabolites in plants provides health benefit foods.

From the previous results, it is clear that germination brought significant increases in the micronutrient, phyto-nutrient content of radish seed, thus proving that there is clear increasing in the nutritive value of the seeds on sprouting. Besides, clarification to some extent the behavior of natural and food-grade elicitor responses which is an important step towards the future development of valueadded foods with elicited phytochemicals.

This study could help in laying the basis for future research on improving the nutraceutical value of plant foods using natural elicitors. 


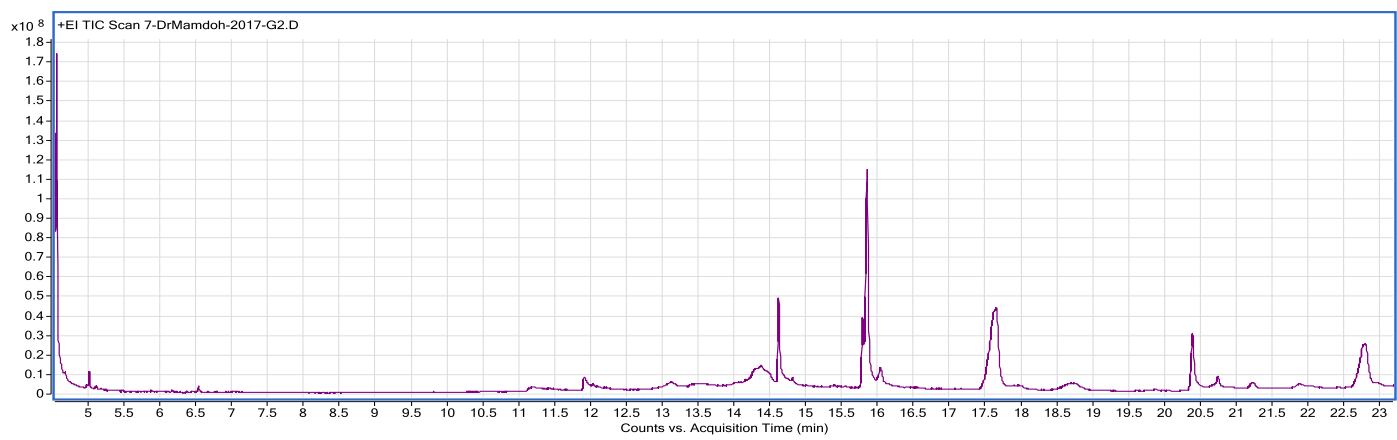

Fig. 1. GC/MS chromatogram for radish seed

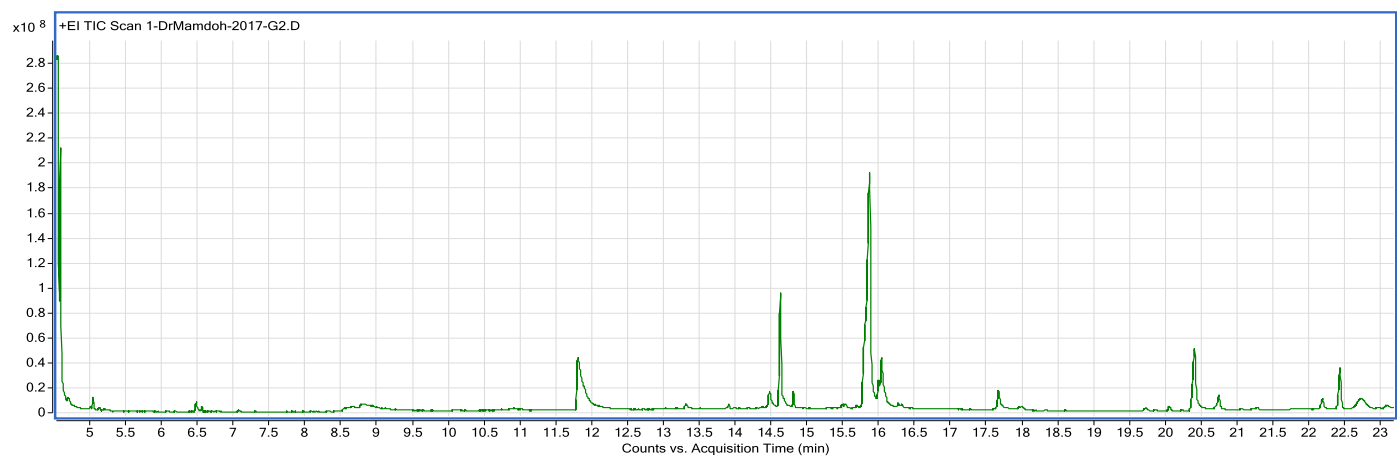

Fig. 2. GC/MS chromatogram for radish sprouts using tap water

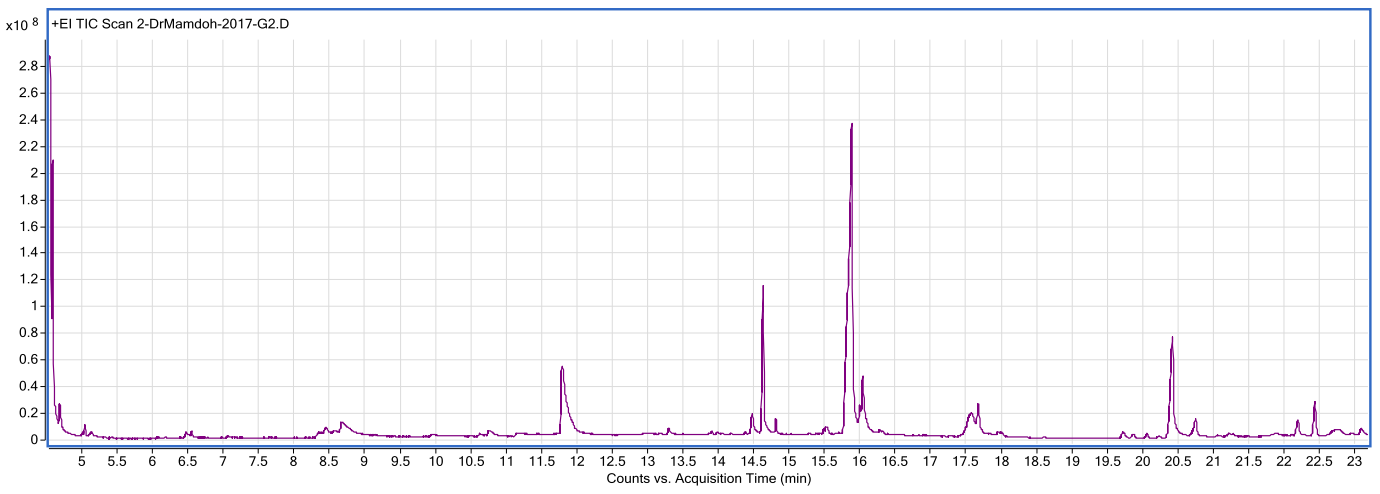

Fig. 3. GC/MS chromatogram for radish sprouts using tap water with SC yeast

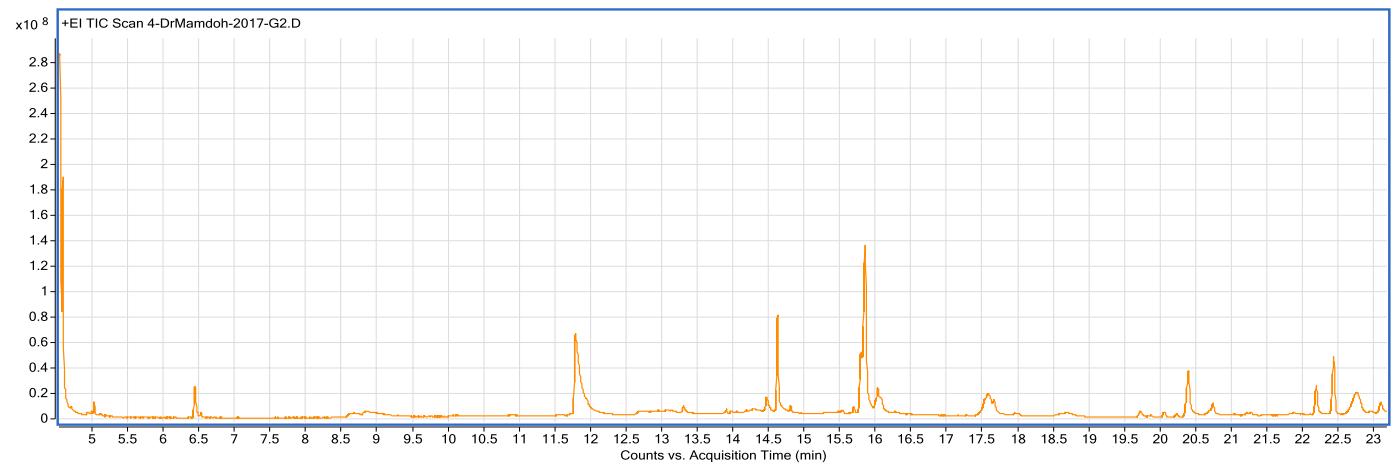

Fig. 4. GC/MS chromatogram for radish sprouts using saline water 


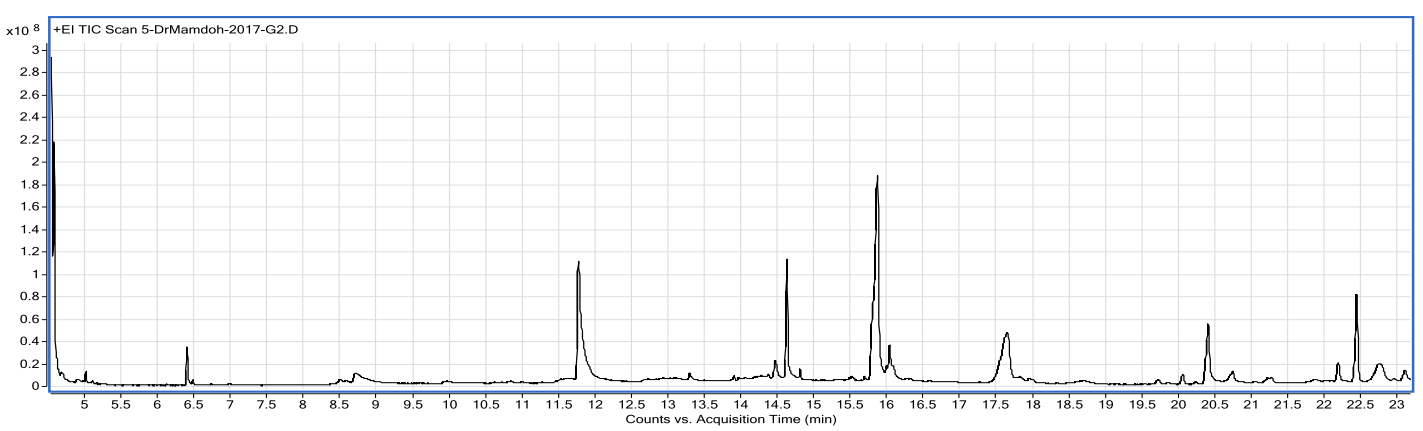

Fig. 5. GC/MS chromatogram for radish sprouts using saline water with SC yeast

Table 6. Phytochemical compounds identified in the ethanolic extract of Egyptian radish seeds and its sprouts using tap and saline water and with Saccharomyces cerevisiae yeast

\begin{tabular}{|c|c|c|c|c|c|c|c|}
\hline \multirow[b]{2}{*}{ NO } & \multirow[b]{2}{*}{ R.T } & \multirow[b]{2}{*}{ Name } & \multicolumn{5}{|c|}{ Area sum \% } \\
\hline & & & Seed & TW & $\mathrm{TW}+$ Sacch. & sw & $\begin{array}{l}\text { SW+ } \\
\text { Sacch }\end{array}$ \\
\hline 1 & 4.574 & 3-Methylmercaptopropanoic acid & 8.76 & 9.46 & 1.85 & 1.07 & 7.12 \\
\hline 2 & 4.676 & Glycol dimercaptoacetate & 0.94 & 1.20 & 0.39 & 0.33 & 1.29 \\
\hline 3 & 4.997 & 5,3'-Dihydroxy-6,7,4'-trimethoxyflavone & 0.92 & 0.56 & 0.38 & 0.59 & 0.59 \\
\hline 4 & 5.002 & $5,7,3^{\prime}, 4^{\prime}, 5^{\prime}$-Pentahydroxyflavone & - & 0.23 & 0.64 & 0.38 & 0.69 \\
\hline 5 & 5.034 & L-Cysteine & 0.71 & 0.71 & 0.32 & 0.46 & 0.26 \\
\hline 6 & 5.132 & $\beta$-Curcumene & 0.42 & 0.52 & 0.46 & 2.11 & 1.48 \\
\hline 7 & 5.197 & Tetrahydrothiophenesulfoxide & - & 0.48 & - & - & - \\
\hline 8 & 6.48 & Phloroglucinol & - & 0.83 & 0.69 & 0.65 & 0.59 \\
\hline 9 & 6.566 & Methoxyeugenol & 0.53 & 0.70 & 1.08 & 0.32 & 0.60 \\
\hline 10 & 7.083 & $\beta$-Terpinyl acetate & - & 0.28 & 0.52 & 0.47 & 1.06 \\
\hline 11 & 8.432 & $3(2 \mathrm{H})$-Isothiazolone, 2-octyl- & - & - & 2.19 & 1.65 & 0.55 \\
\hline 12 & 8.468 & Thiophene, 2-butyltetrahydro- & - & 2.13 & 3.50 & 4.28 & 2.01 \\
\hline 13 & 8.697 & 4-Methylthio-3-butenyl isothiocyanate & - & 4.26 & 1.62 & 1.10 & 1.22 \\
\hline 14 & 10.766 & diNonyl sulfide & - & 1.06 & 1.00 & 0.33 & 0.78 \\
\hline 15 & 11.173 & a-d-Glucofuranosylbenzenesulfonate & 1.78 & 0.78 & 8.17 & 16.06 & 12.42 \\
\hline 16 & 11.78 & 4-tert-Butyl-o-Thiocresol & 3.01 & 9.47 & 1.57 & 1.01 & 1.01 \\
\hline 17 & 13.288 & (+)-a-Tocopherol & 1.40 & 1.75 & 1.35 & 0.75 & 1.24 \\
\hline 18 & 13.895 & Linoleic acid & 2.85 & 1.55 & 1.67 & 1.58 & 1.49 \\
\hline 19 & 14.461 & Ascorbic acid, permethyl- & 7.27 & 1.63 & 7.25 & 5.76 & 4.92 \\
\hline 20 & 14.62 & Eicosanoic acid & 5.65 & 6.05 & 0.84 & 0.67 & 0.52 \\
\hline 21 & 14.799 & Oleic Acid & 1.21 & 0.89 & 0.92 & 0.83 & 1.13 \\
\hline 22 & 15.512 & Isopropyl linoleate & 1.37 & - & 31.32 & 3.86 & - \\
\hline 23 & 15.883 & Erucic acid & 3.96 & 0.86 & - & 14.68 & 20.37 \\
\hline 24 & 16.00 & Biotin & - & 1.52 & - & - & - \\
\hline 25 & 16.017 & Isolongifolol & - & 27.38 & 1.27 & - & - \\
\hline 26 & 16.03 & Stearic acid & - & 2.38 & 2.30 & 3.49 & 3.09 \\
\hline 27 & 16.266 & Quercetin 3,5,7,3',4'-pentamethyl ether & 15.88 & 0.84 & 0.68 & 0.89 & 1.09 \\
\hline 28 & 17.561 & Squalane & 2.92 & - & 4.63 & 4.79 & - \\
\hline 29 & 17.667 & Phytol & - & 2.24 & 1.84 & 2.35 & 9.12 \\
\hline 30 & 17.814 & 9-Octadecenamide, (Z)- (CAS) & - & - & 0.79 & - & - \\
\hline 31 & 17.94 & 22-Tricosenoic acid & - & 0.74 & - & 0.55 & 0.46 \\
\hline 32 & 18.67 & Y-Sitosterol & 21.88 & - & 0.87 & 2.40 & 2.17 \\
\hline 33 & 19.708 & cis-10-Nonadecenoic acid & - & 0.85 & - & 1.23 & 0.95 \\
\hline 34 & 19.847 & Methyl nervonate & 4.25 & 0.56 & 0.73 & 0.56 & 0.31 \\
\hline 35 & 20.038 & Octacosane & 1.38 & 0.74 & 0.83 & 1.15 & 0.83 \\
\hline
\end{tabular}


Table 6. Cont.

\begin{tabular}{|c|c|c|c|c|c|c|c|}
\hline \multirow[b]{2}{*}{ NO } & \multirow[b]{2}{*}{ R.T } & \multirow[b]{2}{*}{ Name } & \multicolumn{5}{|c|}{ Area sum $\%$} \\
\hline & & & Seed & TW & TW+Sacch. & SW & $\begin{array}{l}\text { SW+ } \\
\text { Sacch }\end{array}$ \\
\hline 36 & 20.426 & 13-Docosenoic acid, methyl ester & 5.92 & 5.54 & 7.94 & 4.74 & 5.10 \\
\hline 37 & 20.731 & Palmitic acid, ethyl ester & 2.29 & 1.62 & 1.07 & 1.15 & 0.94 \\
\hline 38 & 21.261 & Phytanic acid & - & 0.64 & 1.39 & 1.40 & 1.21 \\
\hline 39 & 21.876 & $\begin{array}{l}\text { 3'-Hydroxy-5,6,7,4'- } \\
\text { tetramethoxyflavone }\end{array}$ & - & 0.62 & 0.80 & 1.40 & 1.47 \\
\hline 40 & 22.169 & 1-Hexacosanol & 2.34 & 0.72 & 1.15 & 2.88 & 1.84 \\
\hline 41 & 22.414 & Heptadecane, 2,6,10,15-tetramethyl- & 2.35 & 3.39 & 2.01 & 4.79 & 5.08 \\
\hline 42 & 22.723 & $\beta$-Sitosterol & 12.05 & 3.07 & 2.90 & 5.09 & 2.92 \\
\hline 43 & 22.939 & cis-Vaccenic acid & - & 0.87 & 1.11 & 0.54 & 0.50 \\
\hline 44 & 23.07 & Isovitexin & - & 1.09 & 1.06 & 1.64 & 1.58 \\
\hline
\end{tabular}

R.T: Retention time

(Tw):tap water, (TW+Sacch.):tap water + Saccharomyces cerevisiae, (SW):Slain water, (SW+SC):Slain water + Saccharomyces cerevisiae yeast

\section{REFERANCE}

Aly, Tahany, A.A., 2015. Biochemical studies of antidiabtiec effect of some seed sprouts in adult male albino rats. Ph.D. Thesis Dept. of Biochemistry, Fac. of Agric. Cairo Univ. 169p.

Aly. Tahany A.A., ElRahim E.A., Fayed S.A., Amal M. Ahmed and Abdallah M.M.F., 2018. Influence of sprouting on chemical composition and protein qulity of radish (Raphanus sativus) and clover (Trifolumalex andrinum) seeds. J. Biol. Chem. Environ Sci., 13(1), 339-355.

AOAC, 2012. Official Methods of Analysis of Official Analytical Chemists $19^{\text {th }}$ Ed. Chapter 4, pp. 9-56. Washington, D.C., USA.

Baenasa, N., Gómez-Jodarb, I., Morenoa, D.A., García-Vigueraa, C., Periago, P.M., 2017. Broccoli and radish sprouts are safe and rich in bioactive phytochemicals Nieves Baenasa. Postharvest Biology and Technology 127, 60-67.

Dongyan, T., Yinmao, D., Hankun, R., Li, L. and Congfen, H., 2014. Areview of phytochmistry, metabolite changes and medicinal uses of the common food mung bean and its sprouts (Vigna radiate). Chemistry Central J. 8(1), 14.

Eman, M.Tork, 2017. Radish seed sprouting using saline water and their biochemical and pathological effects on albino rats. M.Sc. Thesis, Fac. Agric., Ain Shams Univ., pp. 1-91.

Fouad, A.A. and Rehab, F.M., 2015. Effect of germination time on proximate analysis, bioac- tive compounds and antioxidant activity of lentil (Lens culinaris Medik) sprouts. Acta Sci Pol Technol Aliment. Jul-Sep., 14(3), 233-246.

Marton, M., Mándoki, Z., Csapo-Kiss, Z., and Csapo, J., 2010. The role of sprouts in human nutrition. A Review. Acta Univ. Sapientiae, 3, 81-117.

Mulabagal, V. and Isay, H.S., 2014. Plants cell culture. As alternative and efficient source for the production of biologically important secondary metabolites. Int. J. Appl. Sci. Eng., 2(1), 29-48.

Raskin, I., Ribnicky, D.M., Komarnysky, S., Hic, N., Poulev, A., Borisjuk, N., Brinkler, A., Morena, D.A., Ripoll, C., Yakoby, N., O'Neal, J.M., Cornwell, T., Pastor, I. and Fridlender, B., 2002. Plants and human health in the twenty-first century. Elsevier Science. Trends in Biotechnology, 20(12), 522-532.

Santana, P.M., Miranda, M., Payrol, J.A., Silva, M.; Hernández, V. and Peralta, E.P., 2013. Gas chromatography-mass spectrometry study from the leaves fractions obtained of vernonanthura patens (Kunth) $\mathrm{H}$. Rob. Intern. J. Org. Chem., 3, 105-109.

Sarinont, T., Amano, T., Kitazaki, S., Koga, K., Uchida, G., Shiratani, M. and Hayashi, N., 2014. Growth enhancement effects of radish sprouts: atmospheric pressure plasma irradiation vs. heat shock. $26^{\text {th }}$ International Symposium of Plasma Sciences for Materials Sp. Issue, J. Physics: Conference Series 518, 012017, DOI: 10.1088/17426596/518/1/012017. 
Influence of sprouting using biotic and abiotic elicitors on chemical composition of 725 radish seeds (Raphanus sativus)

Wagner, A.E., Terschluesen, A.M., Rimbach, G., 2013. Health promoting effects of Brassicaderived phytochemicals from chemopreventive and anti-inflammatory activities to epigenetic regulation. Oxid. Med. Cell Longev. Article ID 964539, 12 p.

Zhao, G., Zhao, J., Peng, L., Zou, L., Wang, J., Zhong, L. and Xiang, D., 2012. Effects of yeast polysaccharide on growth and flavonoid accumulation in Fagopyrum tataricum sprout cultures. Molecules 17, 11335-11345.

Zhao, J.L., Zhou, L.G., Wu, J.Y., 2010. Effect of biotic and abiotic elicitors on cell growth and tanshinone accumulation in Sativa miltiorrhiza cell culture. Appl. Micro. and Biotech., 87(1), 137-144. 



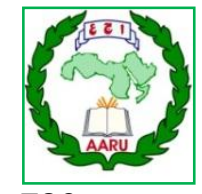

المؤتمر الرابع عشر لبحوث التنمية الزراعية،

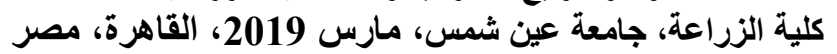

مجلا(27)، عدد (1)، عدد خاص مارس، مارس، 2019

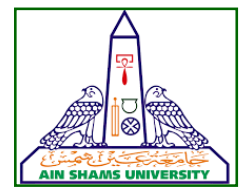

تأثير عملية التنبيت بإستخدام المحفزات الحيوية وغير الحيوية على المكونات الكيميائية

\title{
ل بلبذور الفجل
}

[66]

\author{
إسلام محمد ترك+1- أحمد عبد الوهاب محمد عبد الحافظ²- فاطمة أحمد على مصطفى13 \\ 3

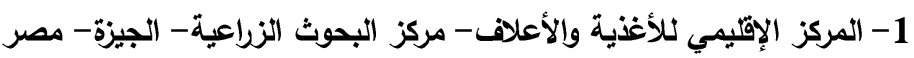

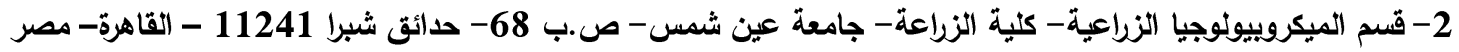

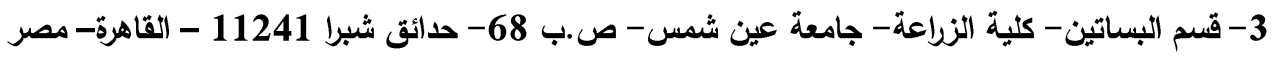

*Corresponding author: islamtork2008@gmail.com

Received 13 October, 2018, $\quad$ Accepted 31 October, 2018

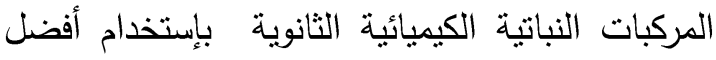

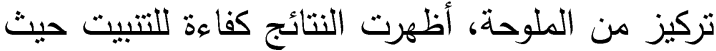

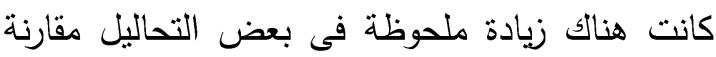

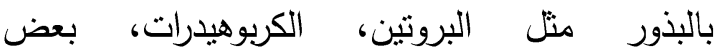

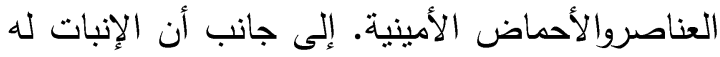
تأثير إيجابى لظهور مركبات نباتية كميائية ثانوية منل الأنل

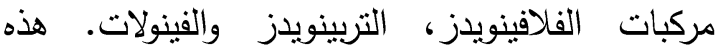
الدراسة والدراسات المتثابهة خطوة هامة إنبات إتجاه التطور كقيمة غذائية مضافة بإستخدام المحفزات الحيوية وغير التهاه

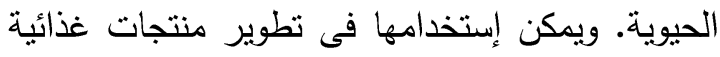
مبتكرة ذات تأثثير مفيد لصحة الإنسان.

الكلمات الدالة: بذور الفجل، المحفزات، حيوي، غير

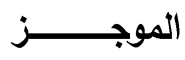

الإنبات هو وسيلة لتحسين الإنتاجية الزراعية وسهلة

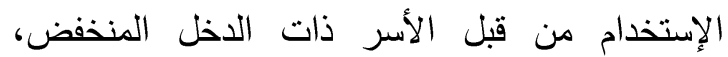

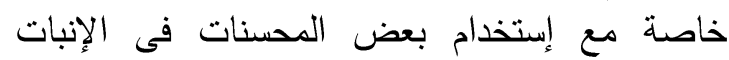
لتحسين القيمة الغذائية لنبت البذور • فِى هذه الدراسة فئنة

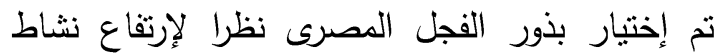
معدلات الأيض بعد الحصاد. تم بحث تأثثر لثرن محفز

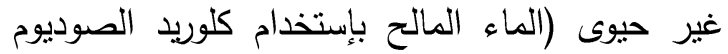
Saccharomyces ( بتركيزات مختلفة) ومحفز حيوى ليول (cerevisiae

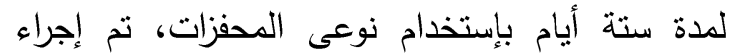

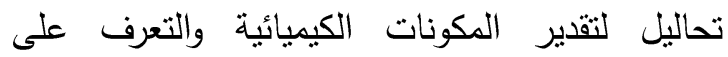

